\title{
APHIS BAKERI AND SOME ALLIED SPECIES
}

\author{
C. P. Gullette and L. C. Braga
}

In our aphid studies we have often been puzzled in the placing of several rather closely allied forms that might be grouped around $A$ phis bakeri on account of their resemblance to this species. Probably there are other species that will fall in to this same group, but they are not known to us now.

The species treated in this paper all have short cornicles, in most cases, little, if any, longer than the hind tarsi and cylindrical in form. The cauda is rather short and broad, and in most of the species decidedly short and blunt. The antennæ are shorter than the body with the third joint heavily set with tuberculate sensoria; joint 4 also has sensoria, usually somewhat tuberculate, and joint 5 may or may not have sensoria aside from the permanent one near the distal end. The filament varies to a considerable extent in length in the different species, but never is shorter than joints 5 and 6 taken together in the alate forms.

We have been able to separate the species we have studied by the following key:

\section{Key for Alate Vtviparods Forms}

Cornicles smooth, not having transwerse rows of ridges or chitinous points. .helichrysi Cornicles having many transverse rows of chitinous points.

A. Hind tibix with numerous sensoria.

a. Sensoria on distal half of tibia (absent on fall migrants)...... viburnicola

b. Sensoria on proximal half of tibia (also on tibia of apterous viviparous form, but not on males) $\ldots \ldots \ldots \ldots \ldots \ldots \ldots \ldots \ldots \ldots$ sensoriata $\mathbf{n}$. sp.

AA. Hind tibiæ without sensoria.

Beak not surpassing hind coxæ $\ldots \ldots \ldots \ldots \ldots \ldots \ldots \ldots \ldots \ldots \ldots \ldots$ baki

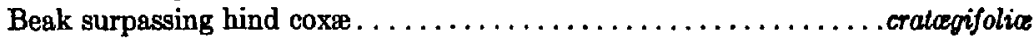

APHIS HeLichrysi Kalt. (Fig. 12, 1-5)

Aphis helichrysi Kalt., Monographie der Pflanzenlause, 1843, p. 102.

Aphis myosotidis Koch., Pflanzenlause, 1857, p. 57.

A phis helichrysi Koch., Pflanzenlause, 1857, p. 135 (not this species).

A phis marutae Oest., Aphididæ of Minn., 1887, p. 57.

Brachycaudus helichrysi, V. d. Goot., Zur Systematik der Aphiden, 1913, p. 97.

Brachycaudus helichrysi, V. d. Goot., Kenntnis der Hollandischen Blatt-Lause, 1915, p. 256.

The above list of the more important papers treating of this species, gives the synonymy as we see it. We have Aphis helichrysi and $A$. myosotidis from Europe as determined by Van der Goot, and a large collection of what we have been considering to be marutce on a variety of host plants, and we are unable to separate them from one another, so we think they all should fall under helichrysi Kalt. 
This species feeds chiefly upon composites, but not exclusively. Our records of food plants and dates of capture are as follows:

Place

Fort Collins

Fort Collins

Woods Hole, Mass.

Fort Collins

Fort Collins

Fort Collins

Boulder

Fort Collins

La Porte

Palo Alto

California

Fort Collins

Fort Collins

Fort Collins

Fort Collins

\section{Date}

Collector

11- 4-07

6-15-09

L. C. Bragg

L. C. Bragg

7- 3-09

10-28-10

5-14-11

5-16-11

6-24-11

9-30-11

L. C. Bragg

L. C. Bragg

L. C. Bragg

L. C. Bragg

L. C. Bragg

L. C. Bragg

9-29-11

4-26-12

L. C. Bragg

H. Morrison

1-11-13

1-27-15

3-29-16

6- 1-16

12- 5-17
W. M. Davidson

L. C. Bragg

L. C. Bragg

L. C. Bragg

L. C. Bragg
Food Plant

Form

Tanacetum balsamila alate, apterous Achillea sp.

apterous

Anthemis sp.

Carduus sp.

Senecio sp.

Urtica

Onosmodium sp.

Ambrosia

artemisifolia

Eupatorium sp.

Amsinckia

intermedia

Helianthus

Cineraria sp.

Bursa bursa

Apple

Malva sp.

Other plants on which this species has been taken in Colorado are Carrot, Chrysanthemum, marguerite, Carum, heliotrope, Phacelia and Lithospermum.

The types described by Kaltenbach were taken from Helichrysum chrysanthemum, "Balsamite," Anthemis tinctoria and Achillea patarmica in Europe, all composites. In northern Colorado this species often occurs in special abundance on Ambrosia artemisifolia, and Erigeron canadense, and, of the cultivated plants, Tanacetum balsamita and Cineraria.

A peculiar thing in connection with this louse, which is very noticeable where it is abundant upon the plant, is the hard excretion which seems not to be liquid, and which gives a frosted appearance to the foliage upon which it accumulates.

In addition to what is given in the above key, it might be stated that this is the smallest of the group considered, large alate individuals seldom exceeding $1.35 \mathrm{~mm}$.; the antennæ is nearly as long as the body; the cornicles taper slightly in the alate form, and more noticeably in the apterous form, from the base towards the tip. We have found no evidence of either sexual forms or eggs.

Aphis viburnicola Gillette (Fig. 12, 6-12)

Aphis viburnicola Gill., Entomological News, 1909, p. 280.

This is an abundant species every spring and fall upon the snowball bushes, (Viburnum), and to the present, has eluded all attempts to 
locate the summer food plant. It seems quite closely allied to the new species, sensoriata. The characters shown in figures 6 to 12 of the accompanying plate will serve to separate it readily from any other aphid known to us.

Our records on this species are very numerous. All the young of the stem mother acquire wings and leave the curled leaves for some other food plant. The sexupara begin to return early in September, the males coming a little later, when the earliest born oviparous fomales are about half grown.

\section{ApHis sensoriata, new species (Fig. 12, 13-26)}

Described from alcoholie material taken by L. C. Bragg at Log Cabin, Colorado, July 27, 1917, altitude 8,000 feet, and by C. P. Gillette, at Fort Lewis, Colorado, October 1, 1917, altitude 8,800 feet. In both cases the lice were infesting the leaves of Amelanchier sp. The July specimens are all apterous viviparous, and the October specimens include alate sexupara, alate males and oviparous females.

Apterous Viviparous Female, Summer Form. The specific name is suggented by the presence of sensoria upon the hind tibix of adult alate and apterous virgogenia, the young apterous virgogenia and the oviparous females, and the irregularity of the occurrence of sensoria on the antenna, especially of the apterous virgogenia, where the number varies from zero to 18 on the third segment among the 10 apparent adults we have.

General color some shade of green with transiverse black or blackish markinga upon the segments of the abdomen above, and a large blotch covering most of the dorsum of segments 4, 5, and 6, at least. In life, the color is black or blackish throughout, with cornicles pale greenish yellow to blackish in the older examples; antenne, lege, cornicles and cauda black or dusky; beak attaining or even surpassing hind coxæ; cornicles short $(.15 \mathrm{~mm}$.), and gradually tapering from base to tip; cauda short and broadly oval at tip, not longer than width at base; length of body, 2 to $2.25 \mathrm{~mm}$; width, 1.30 to $1.50 \mathrm{~mm}$.; length of antenna, 1 to $1.10 \mathrm{~mm}$.; joints of antenna in the following proportions: I, 10; II, 8; III, 32; IV, 22; V, 22; VI, 10; spur, 27; joint III having from 0 to 18 oval or circular sensoria. In all but one example, the sensoria on joint III vary from 0 to 2 , and on joint IV from 0 to 6 . Hind tibia $.80 \mathrm{~mm}$. in length with numerous, small oval sensoria on the swollen basal half. Small apterous lice, down to $1.25 \mathrm{~mm}$. in length, all have the hind tibiæ swollen and with sensoria, but with a smaller number than the adult. Figure 19, of Plate I shows the tibia of a nymph that does not appear to be beyond the second moult. Soe figures 13 to 19 .

Alate Viviparous Female, Summer Form. Described from examples taken at Log Cabin, Colorado, July 26, 1917, and at Fort Lewis, October 1, 1917.

General color, black or blackish throughout; basal portions of femora and tibim brown; antenne, cornicles and cauda black; cornicles slightly tapering towarde the tip and as long as hind tarsi; csuda blunt and not longer than width at base; antenno $1.20 \mathrm{~mm}$. long, nearly attaining base of cornicles; joints of antenne in the following proportions: I, 7; II, 7; III, 42; IV, 26; V, 23; VI, 11; spur, 
4atis hellichcysil $\times 80$

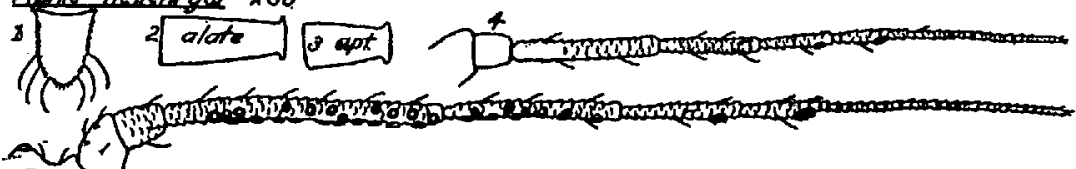
5

Aptis viberaicate $\times 80$

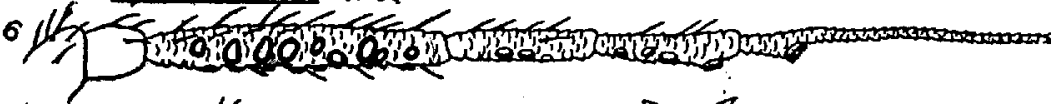

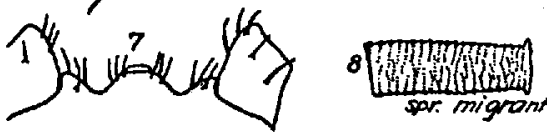

$\leq 2 \leq<\leq<-20<2$

sifis

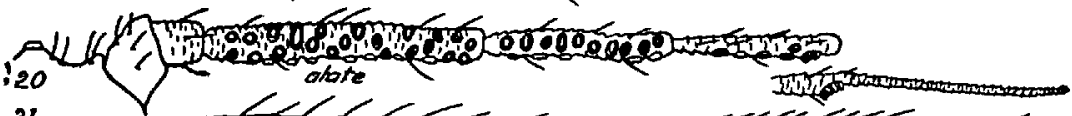

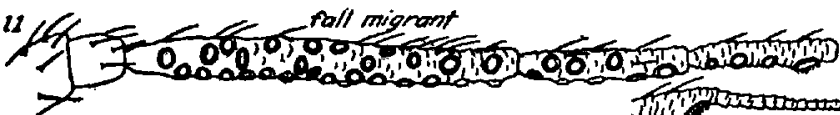

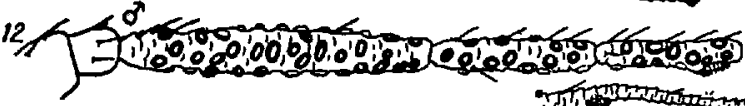

Aphis senseciathe nisa

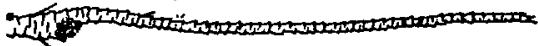

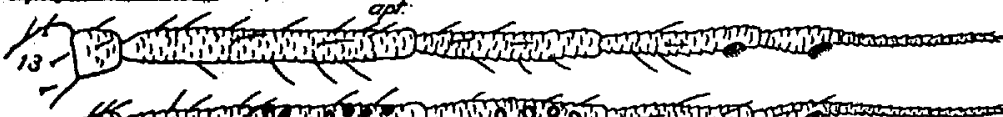
4.

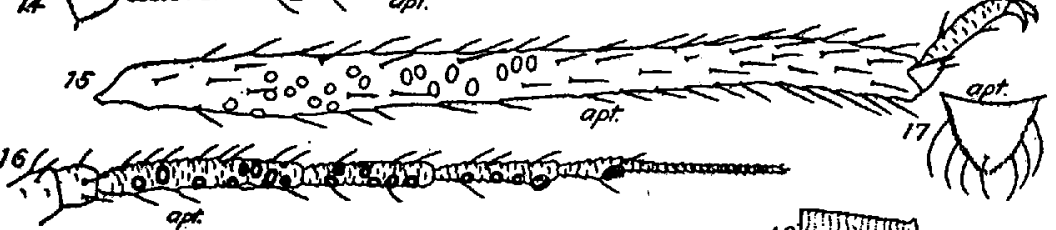

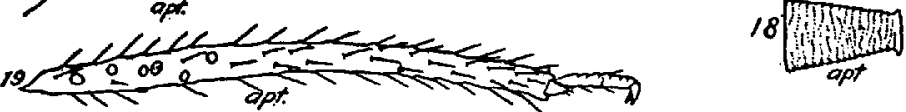

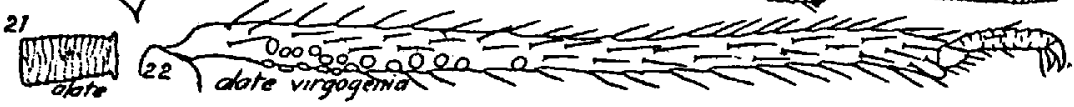

$23040<$ alate sexpana

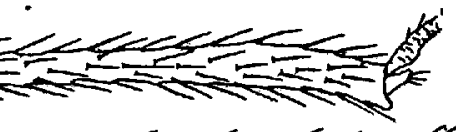

24 1.

24 of 25)

F10. 12 
Aphis bakeri $\times 80$

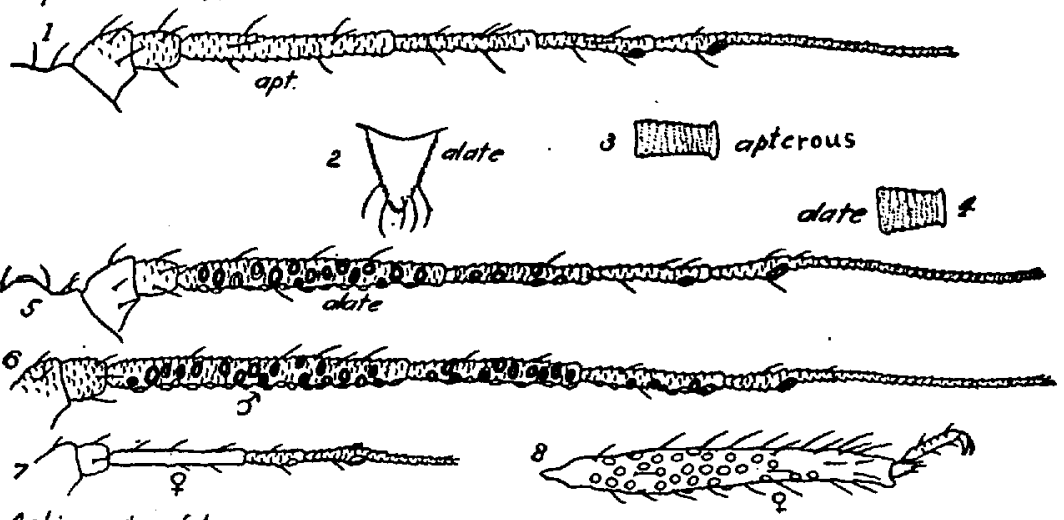

Aphis cratequfolia

Fig. 12. Aphis helichrysi. 1, cauda; 3 , cornicle; 4, antenna of apterous virgogenia; 2 , cornicle; 5 , antenna of alate virgogenia.

A phis viburnicola. 6, antenna; 7, vertex; 8, cornicle; 9, cauda; 10 , hind tibia of spring migrant; 11, antenna of fall migrant; 12 , antenna of male.

Aphis sensoriata. 13,14 and 16 , antennæ; 15 , hind tibia; 17 , cauda; 18 , cornicle of adult apterous virgogenia; 19 , tibia of nymph; 20 , antennæ; 21 , cornicle; 22 , hind tibia of alate virgogenia; 23 , hind tibia of alate sexupara; 24 , antenna of male; 25 , antenna; 26 , hind tibia of oviparous female.

Fig. 13. Aphis bakeri. 1, antenna; 3, cornicle of apterous virgogenia; 2, cauda; 4 , cornicle; 5 , antenna of alate virgogenia; 6 , antenna of male; 7 , antenna; 8 , hind tibia of oviparous female.

A phis cratagifolio. 9, antenna; 10 , vertex; 11 , cauda; 12 , cornicle of alate virgogenia; 13, antenna of sexupara.

All figures enlarged 80 diameters. Original, Miriam A. Palmer, Delineator. 
Alate Malms. Examples taken along with the sexupara described above. Color of abdomen apparently lighter than in the alate viviparous forms; length, $1.40 \mathrm{~mm}$.; antenna (figure 24) as long as the body, filament about as long as joints $V$ and VI combined; sensoria on joint III, about 50 ; joint IV, about 35 ; joint $V$, about 25 ; and joint VI with permanent sensoria only; cornicles shorter than hind tarsi; hind tibiz $70 \mathrm{~mm}$. in length, not swollen at base and entirely without sensoria. The male is very readily separated from the other alate forms, but the spring and fall migrants resemble one another rather closely.

Oviparous Firmale. What appear to be mature apterous egg-layers in alcohol may be described as follows: color almost uniform pale yellow throughout, length 1.25; antennæ .58; and hind tibia $.52 \mathrm{~mm}$.; antenna with permanent sensoria only; hind tibia swollen and set with abundant sensoria throughout its entire length; cauda very broadly rounded posteriorly and broader than long. Examples taken along with the sexupara and males described above from Amelanchier. See figures 25 and 26.

This is an interesting species from a morphological standpoint, and it is very closely allied to viburnicola.

\section{Aphis bakeri Cowen (Fig. 13, 1-8)}

Aphis bakeri Cowen, Hemiptera of Colorado, Bull. 31, Colorado Experiment Station, p. 118, 1895.

Aphis cephalicola Cowen, Hemiptera of Colorado, Bull. 31, Colorado Experiment Station, p. 118, 1895.

A phis bakeri, Gillette, Journal of Economic Entomology, 1910, p. 405.

Aphis bakeri, Gillette and Taylor, Bull. 133, Colorado Experiment Station, p. 28, 1908.

We find this species living throughout the year on clover and giving migrants to apple and Cratcgus in the fall. On occasional years it becomes quite injurious to red clover. This was specially true in northeastern Colorado and parts of Idaho and Utah in 1916, crops being almost ruined in some cases.

\section{Aphis Crataegifoliae Fitch (Fig. 13, 9-13)}

Aphis cratagifolia Fitch, Cat. Hom. N. Y. St. Cab., p. 66, 1851. Aphis cratagifoli Thomas, 8th Rep., Insects of Illinois, p. 101, 1879. Aphis cratagifolia Oestlund, Aphidida of Minn., p. 51, 1887. A phis brevis, Sanderson, 13th Annual Rep., Del. Exp. Sta., p. 157, 1902. Aphis brevis, Patch, Jour. Agr. Res., vol. III, p. 431, 1915. Aphis cratagifolia, Quaintance and Baker, Farmers' Bull. 804, p. 18, 1917.

We have not taken this species in Colorado, but have specimens from other states as follows:

Knoxville, Illinois, September 12, 1907, from Red Haw, J. J. Davis. Orono, Maine, June 14, 1912, from Cratogus, Edith M. Patch.

Winthrop, Maine, October 8, 1913, from Cratcegus, A. C. Baker.

Aphis bakeri occurs freely upon Cratagus in Colorado, but is distinguished by its short beak. 